\title{
Identification and Assessment of Qualification of Griya Sehat in Indonesia
}

\author{
Nurhayati $^{1, *}$, Delima ${ }^{1}$, Ondri Dwi Sampurno ${ }^{1}$, Frans Suharyanto Halim ${ }^{1}$, \\ Lucie Widowati $^{1}$, Hadi Siswono ${ }^{1}$
}

\author{
${ }^{1}$ Center for Research and Development of Health Resources and Service, National Institute of Health \\ Research and Development, Jakarta, Indonesia \\ *Corresponding Author.Email:nurhayati.litbangkes@gmail.com
}

\begin{abstract}
Complementary traditional health service is a treatment system based on the philosophy of the completeness of human being, so that the patients are viewed holistically and culturally and are treated more humanly. Complementary traditional health service is done by professionally educated traditional health worker within traditional health house service facility. Objective: This study aimed to get the health house candidates which held their services according to the Traditional Health House Service Guideline. Method: This was a cross sectional study. The data was collected in qualitative and quantitative fashion. The sample were health service facilities which held traditional health services, their manager, and their traditional health service practitioners concordant with inclusion and exclusion criteria. The qualitative data was collected through in-depth interview, and the quantitative data was collected through interview and observation of the infrastructure in the facility. Result: The result showed that among the 21 facilities visited, $31.3 \%$ (7) were owned by the government and $67.7 \%$ (14) were owned by individuals. The license were $14.3 \%$ (3) from the central government, $19 \%$ (4) from the district government, $47.6 \%$ (10) from the health office, and 19\% (4) did not have license. The types of service in the facility consist of $76.2 \%$ (16) herbal, $71.4 \%$ (15) acupuncture, $71.4 \%$ (15) acupressure/massage, 66.7\% (14) other services such as spa, bekam, totok, and physiotherapy. The workers who conducted the services were $76.2 \%$ (16) health workers, and $52.4 \%$ (11) traditional health workers. The managers and the people in charge were $19 \%$ (4) traditional health workers, and $81 \%$ (17) other health workers. The approach of the services were $66.7 \%$ (14) promotive, $85.7 \%$ (18\%) preventive, $100 \%$ (21) curative, $76.2 \%$ (16) rehabilitative, and $0.1 \%$ (2) palliative. The presence of documentation of the services path were $62.9 \%$ (13) and the presence of the referral system forms were $0.1 \%$ (2). In those facilities, $66.7 \%$ were used as internship place for traditional health workers or other health workers, $42.8 \%$ (9) as workshop stations for traditional health skills. As many as $61.9 \%$ (13) facilities involved in research activities. Conclusion: There were four candidates for traditional health care facilities for pratama Griya Sehat.

Keywords: service, health, traditional, Griya Sehat
\end{abstract}

\section{INTRODUCTION}

Health development is essentially an effort carried out by all components of the Indonesian nation which aims to increase awareness, willingness, and ability to live a healthy life for everyone in order to realize the highest degree of public health. The objectives of the Ministry of Health's strategic plan for 2015-2019 are to improve public health status, increase responsiveness and protect people from social and financial risks in the health sector. ${ }^{1}$

The Government of Indonesia develops traditional health services as recommended by the World Health Organization (WHO) in the Strategy on Traditional Complementary Medicine in 2014-2023, namely: (a). Building basic knowledge for active management of Traditional and Complementary Health (T \& CM) through appropriate national policies. (b). Strengthen the quality assurance, safety, proper and effective use of Traditional and Complementary Medicine ( $\mathrm{T} \&$ $\mathrm{CM}$ ) by regulating products, services and service providers, and; (c). Support comprehensive health insurance by integrating Traditional and Complementary Medicine ( $\mathrm{T} \& \mathrm{CM}$ ) into the delivery of health services and self-care health. ${ }^{2}$

In Law No. 36 of 2009 concerning health, article 48 mandates that traditional health services (traditional health insurance) is one of the efforts of the implementation of health services in order to realize the highest degree of public health. Health care efforts are carried out in an integrated and comprehensive manner with promotive, preventive, curative and rehabilitative approaches. The government is responsible for planning, organizing, organizing, fostering and overseeing the implementation of health efforts that are equitable and affordable to the community. ${ }^{3}$ 
In Government Regulation Number 103 of 2014 concerning Traditional Health Services it is stated that the types of traditional health services are divided into three groups, namely:1) Traditional empirical health services with human resources of traditional health workers (Hattra) who will be in the health care facility. Traditional empirical health services have been running since time immemorial, as services have declined. 2) Complementary traditional health services with human resources graduated from Indonesian Traditional Health higher education health personnel, who will be in a healthy Griya fasyankes, and 3) Integrated traditional health services, as a merger of complementary traditional health services with conventional, and domiciled at the Puskesmas or hospital. ${ }^{4}$

Complementary traditional health services (complementary traditional health yankes) are the application of traditional health that utilizes biomedical and biocultural science in its explanation and scientifically proven benefits and safety. Complementary traditional health services carried out at health service facilities (fasyankes) must be carried out by competent health workers and in accordance with their authority, as well as supporting the Healthy Indonesia Program which is carried out with 3 main pillars namely the Healthy paradigm, strengthening health services and national health insurance. ${ }^{5}$

In Presidential Regulation No. 72 of 2012 concerning the national health system it is stated that the national health system is implemented through various efforts in the form of services in health care facilities. ${ }^{6}$ Traditional health services as part of health efforts, together with conventional health services are directed at creating healthy communities, independent and fair. Article 11 paragraph 1 of Law No. 36 of 2014 concerning Health Workers states that traditional health workers are included in health workers. ${ }^{7}$ In addition, based on Government Regulation No. 47 of 2016 concerning Health Care Facilities, stated that traditional health care facilities are included in health care facilities. Griya Sehat is a form of traditional health service facility for complementary traditional health services. ${ }^{8}$

Based on several national research results in Indonesia, the utilization of traditional health services in the community is quite high. The results of Riskesdas in 2010 showed that $59.12 \%$ of the Indonesian population consumed herbal medicine, and $95.6 \%$ of the population felt the benefits of herbal medicine. ${ }^{9}$ While the results of Riskesdas in 2013 showed that out of $30.4 \%$ of households in Indonesia utilized traditional health services in the past 1 year. The most common types of traditional health services by households are skills $(77.8 \%)$ and herbs $(49.0 \%) .{ }^{10}$

\section{METHOD}

This is a cross sectional study. The data was collected in qualitative and quantitative fashion. The sample were health service facilities which held traditional health services, their manager, and their traditional health service practitioners concordant with inclusion and exclusion criteria. The qualitative data was collected through in-depth interview, and the quantitative data was collected through interview and observation of the infrastructure in the facility.

\section{RESULTS AND DISCUSSION}

The result showed that among the 21 facilities visited, $33.3 \%$ (7) were owned by the government and $66.7 \%$ (14) were owned by private.

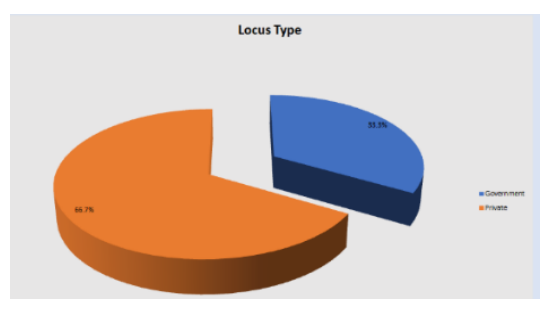

The license were $14.3 \%$ (3) from the central government, $19 \%$ (4) from the district government, $47.6 \%$ (10) from the health office, and $19 \%$ (4) did not have license.The types of service in the facility consist of $76.2 \%$ (16) herbal, $71.4 \%$ (15) acupuncture, $71.4 \%$ (15) acupressure/massage, $66.7 \%$ (14) other services such as spa, bekam, totok, and physiotherapy.The workers who conducted the services were $76.2 \%$ (16) health workers, and $52.4 \%$ (11) traditional health workers.

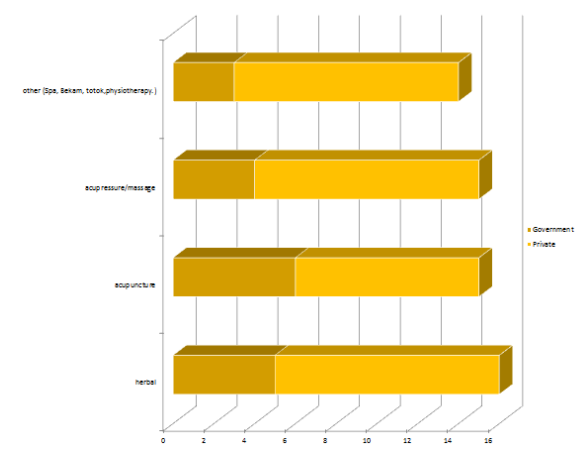

The managers and the people in charge were $19 \%$ (4) traditional health workers, and $81 \%$ (17) other health workers.

The approach of the services were $66.7 \%$ (14) promotive, $85.7 \%$ (18\%) preventive, $100 \%$ (21) curative, $76.2 \%$ (16) rehabilitative, and $0.1 \%$ (2) palliative. The presence of documentation of the services path were $62.9 \%$ (13) and the presence of the referral system forms were $0.1 \%$ (2). In those facilities, $66.7 \%$ were used as internship place for traditional health workers or other health workers, $42.8 \%$ (9) as workshop stations for traditional health skills. As many as $61.9 \%$ (13) facilities involved in research activities. Griya Sehat is a traditional health service facility for traditional health workers (nakestrad).The traditional health worker in question is a health worker who has traditional health skills. Nakestrad's academic level is at least a diploma of three traditional health fields such as herbal medicine, acupuncture, and acupressure. Griya Sehat is a complementary traditional health service facility. 
[11] Badan Litbangkes. 2013. Basic Health Research Report 2013. Jakarta: Indonesian Ministry of Health.

complementary traditional health services are provided in the context of promotive, preventive, curative, and rehabilitative efforts in accordance with professional standards, service standards, and operational procedure standards.

Complementary Traditional Health Services are carried out by traditional health workers. Traditional health workers in using traditional medicines must meet standards and or requirements in accordance with statutory provisions.

Traditional health workers who are unable to provide services in accordance with their competence and authority must refer their patients or clients to health care facilities or other traditional health care facilities. Traditional health service facilities can receive referrals from health service facilities and or health workers.

\section{CONCLUSION}

There are four traditional health service facilities managed by traditional health workers while 17 other traditional health service facilities are managed by health workers. There are four candidates for Griya Sehat pratama. The guidance and surveillance were still needed in those facilities, especially regarding to the license, infrastructure standard, standard operational procedure, and reporting system by the district health office.

\section{REFERENCES}

[1] Decree of the Minister of Health of the Republic of Indonesia Number HK.02.02/MENKES/ $52 / 2015$. concerning the Ministry of Health's Strategic Plan for 2015 - 2019.

[2] WHO Traditional Treatment Strategies.2014-2023. Geneva, World Health Organization, 2013.

[3] Law No. 36 of 2009, concerning health.

[4] Government Regulation of the Republic of Indonesia, No. 103 of 2014, concerning Traditional Health Services.

[5] Ministry of Health Republic of Indonesia. 2017. Healthy Griya Guidelines. Jakarta: Directorate of Traditional Health Services, Ministry of Health Republic of Indonesia.

[6] Presidential Regulation Number 72 Year $2 \mathrm{O} 2$ concerning National Health System.

[7] Government Regulation No. 47 of 2016 concerning Health Care Facilities.

[9] Law No. 36 of 2014 concerning Health Workers.

[10] Badan Litbangkes. 2010. Basic Health Research Report 2010. Jakarta: Ministry of Health Republic of Indonesia.
[12] Nurhayati, Hadi Siswoyo, Lucie Widowati, et al. 2016. Traditional Health Care Model. Jakarta: National Research and Development Agency, Ministry of Health.

[13] Regulation of the Minister of Health of the Republic of Indonesia Number 15 of 2018 concerning the Implementation of Complementary Traditional Health Services 